\title{
From Citizens Overview: Which Antecedents' Can Assist to Increase Their Satisfaction Towards the Ubiquity of Mobile Commerce Applications?
}

\author{
https://doi.org/10.3991/ijim.v14i17.16589 \\ Anas A. Salameh ${ }^{(\varpi)}$ \\ Prince Sattam bin Abdulaziz University, Al-Kharj, Saudi Arabia \\ a.salameh@psau.edu.sa \\ Ibrahim A. Abu-AlSondos, Basel J. A. Ali \\ Applied Science University, Eker, Bahrain \\ Abdullah Fahad Alsahali \\ Riyad Bank, Al Riyadh, Saudi Arabia
}

\begin{abstract}
Recently, mobile commerce started to attract the interest of workers in the commercial sector for ease of application, where people can buy and sell items using the internet on a mobile phone. Therefore, this research aims to investigate the extent of citizens' confidence and trust in m-commerce. The study reveals how m-commerce process over time changes the role of trading from the traditional way to the electronic one. The objective of this study is to determine the impact of trust, ease of use on satisfaction in mcommerce among citizens. Data of this research was collected from teaching staff, employees, and students and they numbered 216, the result indicates that there is a positive relationship between research model variables and that all antecedents affected citizens toward the satisfaction of m-commerce.
\end{abstract}

Keywords - Citizens' satisfaction, M-commerce, Intention to use, Trust, Ease of use.

\section{Introduction}

There is no doubt today that buying and selling via mobile devices plays a major role in companies budget around the world (Alkafagi, Salameh, \& Abu-AlSondos, 2019; Blilat \& Ibriz, 2020). e-commerce has recently emerged, and is spreading rapidly. Therefore, $\mathrm{m}$-commerce is expected to be the dominant trade pattern between firms and individuals (Salameh \& Hassan, 2015).

Most people don't prefer going to markets, because m-commerce provides a variety of options and also convenience for the consumer with a similar price of markets with more offers (Abu-AlSondos \& Salameh, 2020).

According to (Loos, AlKhalawi, AlAndijani, Bukhamseen, \& AlDarrab, 2017) Mcommerce importance is related to the purchasing power and growth achieved by the 
concentration of many Arab and international companies on the market. The consumers have become more familiar with m-commerce which is noticed from a large number of requests from global sites such as "Amazon", "Alibaba" and other global sites.

\subsection{Research problem}

Developed countries, including European countries, have come a long way in the field of trust for the people in m-commerce context (Cui, Mou, Cohen, Liu, \& Kurcz, 2020; Lestari, Maksum, \& Kustandi, 2019; Luo, Li, Zhang, \& Shim, 2010).

Literature review represents that $\mathrm{m}$-commerce is still lagging in Developing countries there is no interest and in the m-commerce industry (Cui et al., 2020; Yeh \& $\mathrm{Li}, 2009)$. in the absence of full awareness among individuals in dealing with these modern means. the increasing challenges open the way for many researchers to investigate on this vital subject trust in m-commerce systems. Thus, this study aims to know the factors that affect citizens toward using mobile for purchasing goods and increasing their trust in $\mathrm{m}$-commerce applications.

\subsection{Research questions}

1. What are the factors that affect citizens to increase their trust in m-commerce?

2. What is the reason for the absence of dependence on m-commerce?

3. How much do people trust m-commerce?

4. How can organizations' increase the trust of people for using m-commerce?

\subsection{Research objectives}

The objective of this research is:

1. Identify factors that influence citizens purchasing process through $\mathrm{m}$ - commerce.

2. Identify the reasons for low electronic use.

3. Identify the degree of confidence for citizens on using m-commerce.

4. Presenting solutions to increase the confidence for using electronic m-commerce.

\section{$2 \quad$ Literature Review}

The main goal of this research is to measure the extent to which consumers have confidence in using e-commerce via mobile. this research explores a review of the history for the use of m-commerce, the definition of mobile commerce, the requirements of mobile commerce, how people in use m-commerce, and what future challenges might face. 


\subsection{Theories of technology adoption}

Among the prime theories to describe the innovative diffusion technology came up as a consequence of an agricultural reform adoption that led Rogers to model the variables that influence the selection of innovative agricultural technology by farmers.Rogers (2010)has described diffusion as a process by which an innovation is accepted over time by another member of the social system. The next figure 2 shows the steps of the innovation-diffusion manner as proposed by(Rogers, 2010).

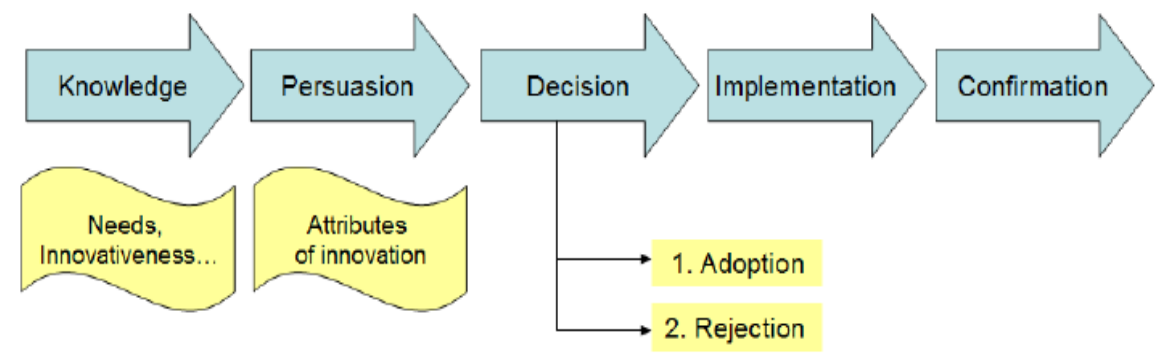

Fig. 1. Stages in innovation diffusion process(Rogers, 2010)

Users first gain awareness on the new technology, which is inspired by their judgments of the new technology, later they view others for more conviction and this involves examining the innovators on their matter concerning the adoption of the latest technology. according to all the information, people settle on the selection of the new technology. This is supported by the real enforcement of their choice and the agreement that the technology has been strongly chosen by the individual. The current model has been used by numerous disciplines inclusive information systems(De Marez \& Verleye, 2004) yet the absence of reasoned discussions on why the technology was used limits its usage in circumstances where the purposes for adoption or refusal need to be spot-lighted and accepted for enhancement (Venkatesh, Morris, Davis, \& Davis, 2003). The model has been involved in more researches on the topic as has been explained in the following sections.

\subsection{The association between trust and satisfaction}

Leninkumar (2017) study was conducted in Sri Lanka, he got a sample of individual customers from particular Commercial Banks. Questionnaires were given to 300 consumers using a convenience sampling approach about 210 were pardon. Therefore, the outcome was that the relationship between consumer trust and satisfaction has is a positive impact in Commercial Banks of the Northern Province.

Kiani, Mustafa, and Ahmad (2019) the results of their study exhibit that both independent factors of brand trust and client satisfaction have a notable influence on client loyalty. Though, client satisfaction is the most crucial aspect of client loyalty in the automobile sector in Pakistan. Accordingly, firms must focus on a complete strategy towards marketing relationship including client satisfaction, which appear in 
keeping current clients and the creation of convinced word of mouth. The study purpose to explore the influence of client satisfaction and brand trust on client loyalty. Data were collected by a self-directed questionnaire from 131 clients from (Rawalpindi/Islamabad) in Pakistan. findings from the questionnaire explained that the correlation between client loyalty and brand trust has a positive impact and a positive relationship with client loyalty and client satisfaction. Thus, a researcher hypothesizes as a following:

- $\mathbf{H}_{1}$.There is a strong association between customer trustand m-commerce customer satisfaction.

\subsection{The association between ease of use and satisfaction}

Wahab, Jusoff, Al Momani, Noor, and Zahari (2011) research explained (e-CRM) marketing and performance strategy that combines technology, people, methods, and all business activities for retaining and attracting clients. There is intense competition in mobile service market area and the amounts of users using mobile phone increasing worldwide this growth triggered researchers to examine the electronic service quality and ease of use as predecessors of the performance of electronic consumer relationship management in the mobile services industry. about 488 questionnaires were returned. current study has explained that the quality of e-service and ease of use were absolutely vital for e-CRM performance.

Pratyaksa (2015) research intended to examine the importance of ease of use, security variables and convenience which have a contemporary and partial impact toward user satisfaction. The variable that was examined is the ease of use, user satisfaction, convenience, security, and user satisfaction. The study sample of Pratyaksa study was 100 participants. Data were processed by a computer program SPSS. The outcomes revealed that there is a powerful relationship between customer satisfaction and security. The outcome from Pratyaksa research explains that the quality of security has been ready to satisfy the association with client satisfaction. Hence, the researchers hypothesize as a following:

- $\mathbf{H}_{2}$.There is a strong association between customer ease of use and m-commerce customer satisfaction.

\subsection{The association between satisfaction and intention to use}

Dondolo and Madinga (2016) study examined the impact of security concerns, ease of use and attitudes toward South African customers' satisfaction about ATM banking services. the study participants were asked via a mailing list for the users of ATM located South Africa. This study reveals that consumer satisfaction is associated strongly with ease of use, attitude and security concerns. indeed, the outcomes show in general that the respondents' user of ATM banking services were satisfied. This research will add valuable knowledge to the body of existing literature. 
Amin, Rezaei, and Abolghasemi (2014) the goal of the research was to determine the influence of trust, perceived ease of use, and perceived usefulness on satisfaction on m-website. A sum of 302 valid questionnaires was obtained for testing the model. For this purpose (SEM) was carried to determine the validity and reliability of structural and measurement model. Outcomes showed that the relationship between PU, PEOU, and mobile users' satisfaction is positively impacted. PU is associated positively upon mobile users' satisfaction and trust.

Furthermore, mobile users' satisfaction is positively influenced by trust. this research develops a framework for customers' satisfaction for using m-services. This research provides new thoughts related to marketing through investigating the influence of trust, PEOU and PU toward mobile consumer' satisfaction and its influence on intention to use m-commerce (Rojas-Osorio \& Alvarez-Risco, 2019). The enrichment of the research is important for both practitioners as well as marketers in the field of the $3 \mathrm{G}$ context. This research is one of the few who tried to combine trust with TAM in order to determine satisfaction of the mobile user. Thus, a researcher hypothesizes as a following:

- H3.There is a strong association between customer satisfaction and m-commerce intention to use.

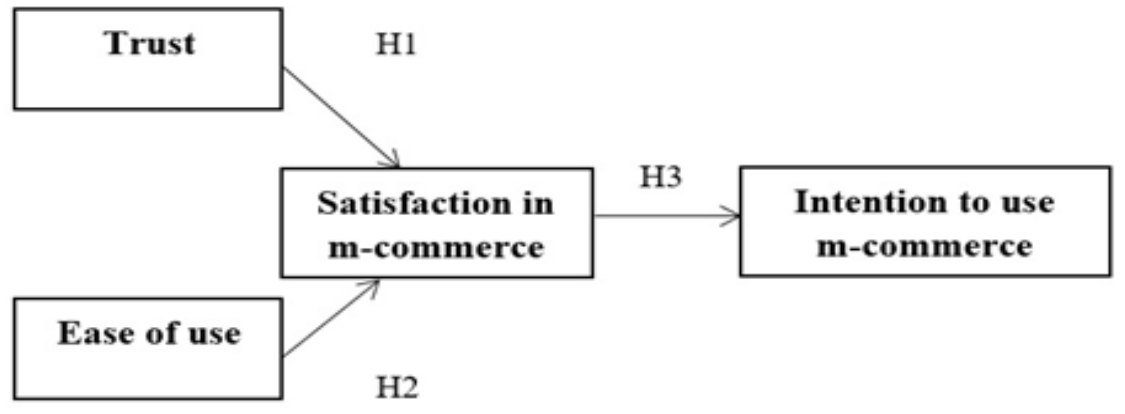

Fig. 2. Research Model

The above explained are displayed in the model Fig. 3, which describes how the mcommerce service quality is defined by, website design, ease of use, and trust.

\section{$3 \quad$ Methodology}

\subsection{Study methodology}

Based on study problems and objectives, the researcher used descriptive approach for this study because it reflects practices and phenomena as they are on the ground which goes beyond data collection and described the phenomena to the analysis and derivation of significant conclusions for the problem addressed by the study. 


\subsection{Population and sampling}

Survey was distributed to 216 members including (males\&females) employs, students and faculty members of the College of Business Administration at the University of Prince Sattam bin Abdulaziz. (SPSS) was used to test research hypotheses.

\subsection{Instrument of the study}

The researcher analyzing previous studies on the theoretical framework for using M-commerce, researcher benefited from this research in the construction of axes and the terms of resolution, the researcher adopted Fifth Likert Scale.

The researcher developed a questionnaire based on the theoretical framework, questions, and objectives. It contained (19) questions divided into three themes:

1. The 1stdomain: The reasons for the lack of dependence on the m-commerce in and it covered by eight items.

2. The 2nd domain: The measure of trust of people in using mobile commerce and it included (5) items.

3. The 3rd domain: increase the trust of people for using m-commerce and it included (6) items.

4. Testing the validity and reliability of the research instrument.

\subsection{Reliability}

The reliability coefficient for the current sample in a manner internal consistency (Cronbach's alpha) of the questionnaire, as shown in table 3.

The correlation coefficient of Cronbach alpha was (\%92.6), which is highly acceptable in terms of making a high statistical study tool useable. The value of the transaction is acceptable consistency of the use of the questionnaire for this study.

Table 1. The reliability test

\begin{tabular}{|c|c|}
\hline Cronbach's Alpha & No. of Items \\
\hline 0.96 & 18 \\
\hline
\end{tabular}

This result was considered satisfactory to use this questionnaire to collect data and analyze them.

\subsection{Measurement items}

Most of the 19 measurement items of this study are adapted from previous questionnaires. All items adapted in this study are considered highly reliable and have strong construct validity as the values of the original Cronbach's alpha of all items ranged between .712 to .960 (Table 3.3). Many researchers have statistically 
recommended a Cronbach's Alpha value that is equal .70 or higher, which considered adequate for any study (Hair et al., 2010; Nunnally \& Bernstein, 1994).

Table 3 indicates the items' number and Cronbach's Alpha values for the measurement instrument from the original study.

Table 2. The Items Number and Cronbach's Alpha Value of Measurement Instrument by the Original Study

\begin{tabular}{|l|c|c|l|}
\hline \multicolumn{1}{|c|}{ Variable } & $\begin{array}{c}\text { Original } \\
\text { No. Of items }\end{array}$ & $\begin{array}{c}\text { Original cronbach's } \\
\text { Alpha value }\end{array}$ & \multicolumn{1}{c|}{ Scale sources } \\
\hline Trust & 8 & 0.89 & $\begin{array}{l}\text { (Hillman, Neustaedter, Bowes, \& } \\
\text { Antle, 2012). }\end{array}$ \\
\hline Ease of use & 3 & 0.79 & (Pratyaksa, 2015) \\
\hline Satisfaction & 4 & 0.87 & (Kiyani, Niazi, \& Niazi, 2012) \\
\hline Intention to use & 4 & 0.84 & (Ting, yacob, liew, \& lau, 2016) \\
\hline Total instruments & 19 & & \\
\hline
\end{tabular}

\section{Summary}

The methodology required to answer the research questions related to the use of mcommerce. Thus, it explains the population, sample, instrument, and procedures of the study.

\section{$5 \quad$ Analysis and Results}

The analysis and results of the gathered data from the study participants. The following includes results concerning background information, ranks of the questionnaire items, and the questionnaire.

\subsection{Respondent data}

The majority of the participants $156(72.2 \%)$ are female, only $60(27.8 \%)$ are male. The distribution number of educations for study respondents study was :( PhD) are 38 (17.59\%), (Master) are 22 (10.18\%), (Bachelor) are $102(47.22 \%)$, (Diploma) are 21 $(9.72 \%)$, (Secondary) is $18(8.34 \%)$, and (Primary) is $15(6.95 \%)$.

\subsection{Analysis}

Table 3. Means and standard deviations for fields of study in descending order of means

\begin{tabular}{|l|c|c|c|}
\hline \multicolumn{1}{|c|}{ Items } & Means & Standard deviations & Rank \\
\hline $\begin{array}{l}\text { The reason for the lack of dependence on mobile } \\
\text { commerce }\end{array}$ & 3.84 & 0.78 & 1 \\
\hline people trust in m-commerce & 3.74 & 0.75 & 2 \\
\hline Increasing the trust of people for using m-commerce & 3.72 & 0.68 & 3 \\
\hline Questionnaire as a whole & 3.76 & 0.69 & $* * *$ \\
\hline
\end{tabular}


Above table 2 presents the means and standard deviations of the study are arranged in descending order according to the arithmetic means, study areas got a high degree of availability with a mean (3.76). So, this table shows that the reason for the lack of dependence on the m-commerce got the highest rank in the average mean of (3.84), standard deviation (0.78), While Increasing the trust of people for using m-commerce got the last rank in the study with (3.72) average and (0.68) standard deviations. This shows the reason for the lack of dependence on m-commerce.

\section{Summary of Findings}

Table 4. . Summary of the Findings

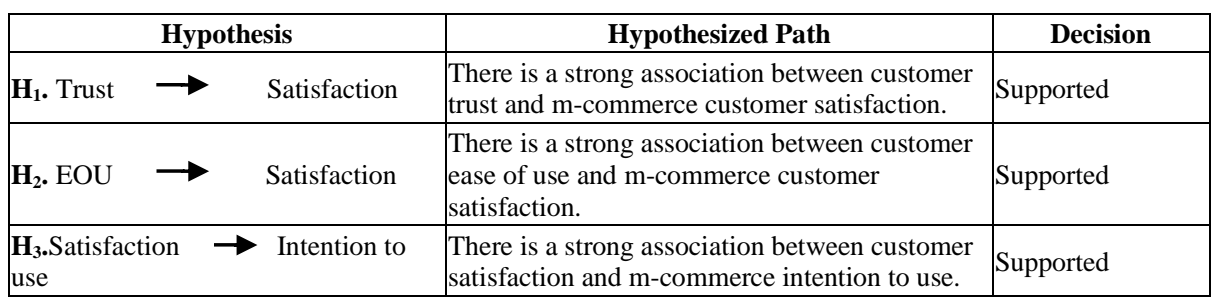

\section{$7 \quad$ Research Implications}

M-commerce is essential to improve the countries economy. they must focus on ICT to take advantages of modern environment and developments by focusing on $\mathrm{m}$ commerce. The importance of this research is to demonstrate the role of electronic commerce in improving economic business. the current study is valuable in setting up specific mechanisms that contribute to increasing revenue from $\mathrm{m}$-commerce and improving the social level of merchants. This study is presenting suggestions and recommendations that lead to finding suitable solutions in the future.

\section{Discussion and Conclusion}

This research addressed m-commerce, based on the results of this study, the researcher can sum the findings of this study as :

1. Trust doesn't have a high effect on m-commerce.

2. the sample that was studied did not respond to making purchases through ecommerce.

3. There is a shortage of a protection system to protect online buyers and ensure their rights.

4. There is no guarantee of refunds during a certain period.

5. The government must intervene to give the confidence to deal.

6. Create an electronic platform that addresses problems such as multiple ads and privacy and guarantees fair tradeoffs. 


\section{Recommendations and Future Directions}

The results of this study provide the researcher several recommendations which shed light on the subject of M-commerce:

1. The government needs to give their concern to regulation that protects consumers when making a mobile purchase.

2. Special legislation must be enacted for online financial transactions that guarantee consumers full rights and impose fines on offenders and violators.

3. It is necessary to focus on a protection system to protect online buyers and guarantee their rights.

The researcher suggests carrying more research in the field of m-commerce, understand their impact on environment, compare the studies that have been in other countries to see their effect on encouraging people to deal with it, improve companies' performance and competition, and improve outcomes.

\section{References}

[1] Abu-AlSondos, I. A., \& Salameh, A. A. M. (2020). The effect of system quality and service quality toward using m-commerce service, based on consumer perspective. Management Science Letters, 10(11), 2589-2596. https://doi.org/10.5267/j.msl.2020.3. $\underline{035}$

[2] Alkafagi, A., Salameh, A. A. M., \& Abu-AlSondos, I. A. (2019). The importance of individual technology factors for adoption of internet banking. European Journal of Business and Management, 11(36), 1-8. https://doi.org/10.7176/ejbm/11-36-01

[3] Amin, M., Rezaei, S., \& Abolghasemi, M. (2014). User satisfaction with mobile websites: the impact of perceived usefulness (PU), perceived ease of use (PEOU) and trust. Nankai Business Review International. https://doi.org/10.1108/nbri-01-2014-0005

[4] Blilat, A., \& Ibriz, A. (2020). Design and Implementation of P2P Based Mobile App for Collaborative Learning in Higher Education. International Journal of Interactive Mobile Technologies, 14(7), 115-132. https://doi.org/10.3991/ijim.v14i07.13167

[5] Cui, Y., Mou, J., Cohen, J., Liu, Y., \& Kurcz, K. (2020). Understanding consumer intentions toward cross-border m-commerce usage: A psychological distance and commitment-trust perspective. Electronic Commerce Research and Applications, 39, 100920. https://doi.org/10.1016/j.elerap.2019.100920

[6] De Marez, L., \& Verleye, G. (2004). Innovation diffusion: The need for more accurate consumer insight. Illustration of the PSAP scale as a segmentation instrument. Journal of Targeting, Measurement and Analysis for Marketing, 13(1), 32-49. https://doi.org/10. 1057/palgrave.jt.5740130

[7] Dondolo, H. B., \& Madinga, N. W. (2016). Ease of use, security concerns and attitudes as antecedents of customer satisfaction in ATM banking. Education, 56, 33. https://doi.org/10.21511/bbs.11(4-1).2016.02

[8] Hillman, S., Neustaedter, C., Bowes, J., \& Antle, A. (2012). Soft trust and mCommerce shopping behaviours. Paper presented at the Proceedings of the 14th international conference on Human-computer interaction with mobile devices and services. https://doi.org/10.1145/2371574.2371593 
[9] Kiani, M. N., Mustafa, S. H., \& Ahmad, M. (2019). Does innovation capabilities affect the new service innovation success among Pakistani cellular companies? Asia Pacific Journal of Innovation and Entrepreneurship. https://doi.org/10.1108/apjie-10-2018-0058

[10] Kiyani, T. M., Niazi, M., \& Niazi, R. (2012). The relationship between brand trust, customer satisfaction and customer loyalty (Evidence from automobile sector of Pakistan).

[11] Leninkumar, V. (2017). The relationship between customer satisfaction and customer trust on customer loyalty. International Journal of Academic Research in Business and Social Sciences, 7(4), 450-465. https://doi.org/10.6007/ijarbss/v7-i4/2821

[12] Lestari, I., Maksum, A., \& Kustandi, C. (2019). Mobile Learning Design Models for State University of Jakarta, Indonesia. International Journal of Interactive Mobile Technologies, 13(9), 152-171. https://doi.org/10.3991/ijim.v13i09.10987

[13] Loos, A., AlKhalawi, N., AlAndijani, A., Bukhamseen, A., \& AlDarrab, M. (2017). UNDERSTANDING THE POTENTIAL OF SCHOOL DATA. Retrieved from http://emkaneducation.com/Madarisna_Understating_the_Potential_of_School_DataEN.pdf

[14] Luo, X., Li, H., Zhang, J., \& Shim, J. P. (2010). Examining multi-dimensional trust and multi-faceted risk in initial acceptance of emerging technologies: An empirical study of mobile banking services. Decision support systems, 49(2), 222-234. https://doi.org/10.1016/j.dss.2010.02.008

[15] Pratyaksa, P. (2015). The Influence of Convenience, Ease of Use and Security on Customer Satisfaction (Study on Mandiri Internet Banking at Mandiri Bank Surabaya Commercial Branch). Jurnal Administrasi Bisnis, 23(2).

[16] Rogers, E. M. (2010). Diffusion of innovations: Simon and Schuster.

[17] Rojas-Osorio, M., \& Alvarez-Risco, A. (2019). Intention to use smartphones among Peruvian University students. International Journal of Interactive Mobile Technologies, 13(3), 40-52. https://doi.org/10.3991/ijim.v13i03.9356

[18] Salameh, A. A. M., \& Hassan, S. B. (2015). Measuring service quality in m-commerce context: A conceptual model. International Journal of Scientific and Research Publications, $5(3), 1-9$.

[19] Ting, H., Yacob, Y., Liew, L., \& Lau, W. M. (2016). Intention to use mobile payment system: a case of developing market by ethnicity. Procedia-Social and Behavioral Sciences, 224, 368-375. https://doi.org/10.1016/j.sbspro.2016.05.390

[20] Venkatesh, V., Morris, M. G., Davis, G. B., \& Davis, F. D. (2003). User acceptance of information technology: Toward a unified view. MIS quarterly, 425-478. https://doi.org/10.2307/30036540

[21] Wahab, S., Jusoff, K., Al Momani, K. A. M., Noor, N. A. M., \& Zahari, A. S. M. (2011). The influence of usability and enjoyment on electronic customer relationship management performance in Jordan mobile communication services. African Journal of Business Management, 5(1), 128.

[22] Yeh, Y. S., \& Li, Y. M. (2009). Building trust in m-commerce: contributions from quality and satisfaction. Online Information Review.

\section{Authors}

Dr. Anas A. Salameh is an Assistant Professor, Department of Management Information Systems, College of Business Administration, Prince Sattam Bin Abdulaziz University since 2016 and the current deputy director of the students' activities committee as well he is a member of the exams scheduling committee, 
PSAU. His major research interest focusing on the area such as e-commerce (mcommerce), e-business, e-marketing, technology acceptance/adoption, e-learning, eCRM, service quality, and he evaluated service quality in many areas related to eservices aspects. Email: a.salameh@psau.edu.sa

Dr. Ibrahim Abu-AISondos is an Assistant Professor of Management Information Systems (MIS) in the college of administrative sciences, Applied Science University (ASU), Kingdome of Bahrain since 2019 and the current Programme leader of bachelor ofManagement Information Systems (BMIS). His research interest includes Knowledge Management (KM), IT-Business Strategic Alignment, E-Business,ECommerce, Mobile Commerce. Email: Ibrahim.abualsondos@asu.edu.bh

Dr. Basel J. A. Ali is an Assistant Professor of Accounting and Finance Department in the college of administrative sciences, Applied Science University (ASU), Kingdome of Bahrain since 2017. His research interest includes accounting such as accounting information system (AIS), corporate governance, and organizational impacts from information system. Email: basel.ali@asu

Abdullah Fahad Alsahli is MIS administrator in the Riyadh Bank since Feb 2020, during his time in the bank, his works focus on writing reports, he has a good knowledge of oracle, excels, and access. He graduated from Prince Sattam Bin Abdulaziz University, College of Business Administration, for the graduation requirements he trained in ERIYADA company, and his tasks at the company were focusing on the projects of the consumers' relationship management of the company. His research focused on m-commerce in KSA. He has a significant contribution to this research especially in finding the research problem (practical and theoretical gap). Email: alambrator10@gmail.com

Article submitted 2020-06-25. Resubmitted 2020-07-26. Final acceptance 2020-07-27. Final version published as submitted by the authors . 